Book Review Symposium "The portability of care in an increasingly mobile world: Chains, drains and circulation"

\title{
Comment 2: Transnational Care: Family Life and Complexities of Circulation and Citizenship
}

\author{
Joan Tronto \\ Minnesota University \\ jctronto@umn.edu
}

\begin{abstract}
This symposium offers a critical discussion of the logics and dynamics behind the new 'care circulation' perspective offered by Loretta Baldassar and Laura Merla in their edited volume entitled "Transnational Families, Migration and the Circulation of Care". This contribution praises the accuracy of this new perspective in family studies, but also reminds us of the continued relevance of the 'care chains approach', in particular as it locates the mobilities of care within debates around global justice. The contribution reflects on some of the blind spots that stem from the 'circulation' metaphor, and highlights in particular the need for the care circulation perspective to place transnational families not only in an institutional, but also a global political context.
\end{abstract}

Keywords: gender; transnational families; migration; citizenship; circulation of care

Resumen. Comentario 2. Cuidado transnacional: vida familiar y complejidades en torno a la circulación y la ciudadanía

Este simposio ofrece una discusión crítica de las lógicas y dinámicas en torno a la nueva perspectiva de la "circulación del cuidado" presentadas por Loretta Baldassar y Laura Merla en su volumen titulado Transnational Families, Migration and the Circulation of Care. Este comentario elogia la precisión de esta nueva perspectiva en los estudios sobre familia, pero al mismo tiempo nos recuerda la vigencia de la aproximación de las «cadenas globales», en la medida que localiza las movilidades del cuidado dentro de los debates en torno a la justicia global. La contribución reflexiona sobre algunos de los puntos negros que surgen de la metáfora de la «circulación» y subraya en particular la necesidad de la perspectiva de la circulación del cuidado para situar a las familias transnacionales no solo en un contexto institucional, sino también en un contexto político global.

Palabras clave: género; familias transnacionales; migración; ciudadanía; circulación del cuidado 
Loretta Baldassar and Laura Merla have edited a wonderful book that allows us to appreciate the ways in which families and care relationships within them are transformed by transnational migration. They make a strong case that a notion of transnational 'care circulation' should replace the simpler notion of global 'care chains.' In this commentary, I would like to praise their greater accuracy in family studies and yet offer one defense for the 'care chains' perspective, despite its inadequacies. After that analysis, the need to place transnational families not only in an institutional, but a global political, context, will emerge.

There is much to admire about this collection. The editors and authors stress a number of critically important points. They insist on the complexity of understanding asymmetrical relationships of care in varieties of different families. They appreciate how care needs change over the life cycle, for both individuals and families. They show how cultural differences from one society to another play out in how families cope with caring in transnational contexts. The comparison of Italian and Caribbean migrants in the UK, and how their shifting understandings of care and family played out, was especially interesting, as was the discussion of care in transnational families in Ghana. They dispute claims that men have no role in caring relationships. They include chapters that discuss middle class, not poor, transnational families. In short, they demonstrate that previous approaches to transnational family caring have overlooked much of the on-the-ground reality for families and individuals.

So the answer should be obvious when one comes to the question: care chains or care circulation, which metaphor is better? Surely as social scientists we should go with the analysis that is more comprehensive and that better reflects the realities of the families involved.

The 'care chain' framing of transnational care giving does have a number of problems. It presumes that care goes only one way in a care relationship, and it privileged some relationships - those of mothers and children — over all others. The metaphor itself, and the way it was developed and used-hearkens back to Nel Noddings' idea that all care is basically dyadic, involving one caring-for and one cared-for (Noddings, 1984). Noddings then transformed all social policies into the sums of care dyads (Noddings, 2002). This is obviously a false position; parents, uncles and aunts and siblings, for example, all care for a child; to focus on the mother-child dyad distorts this reality (and indeed, an entire section of Transnational Care is written to go beyond this simplistic formulation). While I do not want to argue for the superiority of the care chain framework, I do want to dwell upon some aspects of that argument.

The philosopher R. G. Collingwood advised that if we want to understand some human artifact (e.g., a passage in a text, a statue, an ancient Roman fortification, or a family), we learn a great deal if we use the "logic of question and answer," that is, if we consider the object as the answer to some question (Collingwood, 1939). Let me use this logic to raise some concerns about this admirable collection of essays.

If we think about the purpose of the 'care chain' metaphor, its goal was partly social scientific, that is, to provide us with an answer to the question: 
what is happening globally to the families of migrant care workers. But the care chain metaphor misses a great deal about the actual lives of people and their families. We would then be forced to conclude either that the initial scholars were not so good at social science, or we might also ask what other purposes could be served by making this argument? Another obvious answer is that the purpose was a political one. The care chain argument is something of an enthymeme about global justice. The major premise (which was never explicitly stated) was that "It is unjust if some have to sacrifice their own families so that they can care for others." Then the minor premise: "In global care chains, workers cannot adequately care for their own families" leads to the conclusion: the current arrangement of using workers from around the globe to care for the homes and children of those who are relatively well-off is unjust. My language here is more blunt than that used by the authors of 'care chain' scholarship themselves. Ehrenreich and Hochschild, for example, claim that "[t]he globalization of women's traditional role poses important challenges to anyone concerned with gender and economic inequity" (Ehrenreich and Hochschild, 2004:13). Nevertheless, if I am correct, then exposing the invisibility of women as global care workers has a political as well as a social scientific purpose.

The purpose of the care circulation model is to explain with greater accuracy and nuance how transnational families cope with their needs for caring. Since the focus is on families, other issues come less clearly into focus. Normative questions are not directly addressed; several essays consider how families negotiate "normative obligation to give care" (p. 50) but the authors and editors make no normative claims of their own. Since no work of social science can focus on all of the possible questions or dimensions of a topic at once, surely this is enough?

Again, the authors realize that there is a need to situate the transnational families under discussion in a larger context. For example, in a chapter on "A Macro Perspective on Transnational Families and Care Circulation" (pp. 115-129) Laura Merla considers a variety of institutional regimes that provide the context for transnational families: the migration regime, the welfare regime, the gendered care regime, and the working-time regime (pp. 119-120). She points out that visa regulations and family reunion schemes (p. 121) have a huge impact on families. Families end up renegotiating some of their assumptions about obligations and power. And she concludes that "the transnational circulation of care... has consequences that go beyond individual households and wider family networks... (p. 129).

But if we use the logic of question and answer to ask about the central metaphorical switch here, we encounter another concern. 'Circulation' as a metaphor also has consequences that direct our attention towards some issues and away from others. First, circulation naturalizes 'mobility.' Several essays, those by Paola Bonizzoni and Paolo Boccagni and by Marina Ariza, complicate the naturalness of mobility when they cite Zygman Bauman's maxim that the freedom to move is "the main stratifying factor" of today's global society (see, e.g., pp. 88-89; p. 95). Yet to see the freedom to move as a 'stratifying factor' 
obscures the way in which movement is taken to be an expression of freedom. The circulation metaphor obscures several concerns that we might want to take seriously about the nature of global migration. First, there is a presumption with the circulation metaphor that there are ongoing flows of care. But the power differentials that make flows of workers go from one place to another are not interrogated here. And the notion of circulation implies that there is, in the end, some form of balancing out, or equal return within the system. By focusing on individual families and their success or failure in this larger circulatory system, this larger question is not addressed. What is more likely happening, on a global level, is that some caring needs are being met more thoroughly and other caring needs are being met less successfully (Razavi and Staab, 2012). Second, in most circulating systems, there is also a pump or some force that manages to keep the system flowing. In this text, there is no discussion of what the pump might be. Indeed, it is a different pump perhaps, for an Indian student studying in Australia than for a San Salvadorean man who seeks out work in the USA. But to allow these circulations to go on without thinking about their 'pumps' makes the political economy behind these changes less visible. It lowers the horizon of questioning to presume that such circulation is normal and regular.

Interestingly enough, some effects of this normalization of circulation show up in the text itself. While for 'care chain' writers, the political status of individuals and transnational families are an important question (consider Rhacel Parreñas's observation that those in care circulation often possess only 'partial citizenship' [Parreñas, 2001]), none of the essays in this volume focus on the political disenfranchisement that happens to those in transnational families.

Leaving out the political dimension is not, though, in the end, only about politics itself. It may also lead to an incomplete or inaccurate picture of what is happening as well. After all, families rely not only upon cultural norms and expectations in determining how to act, but also upon political understandings of the fate that has befallen them. While there is much discussion of the ways that families negotiate how to manage distance, there is no real focus on the question: how do families decide which family members will travel in the first place? Are they the best and the brightest? If so, does their departure mark a problem for the 'social capital' left in the home country? Do transnational families ever discuss questions of justice among themselves? Do they see what they are doing as a kind of necessity, fulfillment of desire, or something more complex? These questions would arise from a less naturalized and more political framing of the questions considered here. In the first essay, the editors acknowledge that " $[\mathrm{t}]$ he transnational social sphere, while full of circulating people, ideas, goods and finances, remains relatively empty of transnational structures, infrastructures and support services to safeguard these people and their activities and relationships" (Baldassar and Merla, 2014:35). Only an investigation of how citizenship might be transformed in order to make care givers more than 'partial citizens' will prove useful here; one such proposal is the utopian claim that I made that care relationships, whether receiving 
or giving of care, should be the measure of citizenship (Tronto, 2005). This expands the boundaries of citizens substantially, and would be unacceptable to those who think about citizenship as it is connected to sovereignty within a nation state, but it also forces us to confront the political dimensions of transnational family caring.

Given the academic division of labor, this book will be most closely debated in family studies and migration studies. In the end, this approach to care within transnational families surely advances our knowledge of the realities of caring in families across transnational borders. But the framing of care circulation comes with its own limits.

\section{Bibliographic references}

BALDASSAR, Loretta and Merla, Laura (2014). "Locating Transnational Care Circulation in Migration and Famliy Studies". In: BALDASSAR, Loretta and MerLa, Laura (eds.). Transnational Families, Migration and the Circulation of Care: Understanding Mobility and Absence in Family Life. New York: Routledge, 25-58.

Collingwood, Robin George (1939). An Autobiography. Oxford: Oxford University Press.

Ehrenreich, Barbara and Hochschild, Arlie (2004). Global Woman: Nannies, Maids, and Sex Workers in the New Economy (rev. ed.). New York: Holt.

Noddings, Nel (1984). Caring: A Feminine Approach to Ethics \& Moral Education. Berkeley: University of California Press.

- (2002). Starting at Home: Caring and Social Policy. Berkeley: University of California Press.

ParreNas, Rhacel Salazar (2001). Servants of Globalization: Women, Migration, and Domestic Work. Stanford, CA: Stanford University Press.

Razavi, Shahra and StaAb, Silke (2012). Global Variations in the Political and Social Economy of Care: Worlds Apart. London: Routledge.

Tronto, Joan Claire (2005). "Care As the Work of Citizens: A Modest Proposal". In: Friedman, M (ed.). Women and Citizenship. New York: Oxford University Press, 130-145. 